\title{
Editorial
}

\section{Granitos de arena}

Latino Studies (2016) 14, 429-430. doi:10.1057/s41276-016-0014-2

Although mainstream media insists on offering a steady stream of representations of Latinos as for the most part undocumented, dangerous, and foreign, Latinos have played a pivotal role in just about every historical, political, and cultural happening of significance in the US. We are all familiar with the discourse around the "Latino problem," so it is refreshing to encounter writings that interrupt those narrow, inadequate depictions and convey the many granitos de arena Latinos contribute to the fabric and culture of the US. This issue features four original articles that draw attention to experiences of Latinos in an array of industries including music, marketing, seafood processing, and boxing.

Latinos have had a great impact in the music industry, quite often infusing traditional forms with novel and exciting elements. The article by José Navarro offers a provocative reading of the music of the Chican@ alternative band, Las Cafeteras. He argues that the band uses son jarocho to challenge anti-immigrant and other discriminatory politics in the United States. Las Cafeteras produces biting counter-narratives that challenge repressive immigrant politics, gender norms, and the criminalization of Latinos, even while grappling with its own internal contradictions. According to Navarro, the musicians offer a vision of hope and a means of staking a claim in their homeland of East LA as well as other contested borderlands.

Marie Sarita Gaytán similarly sheds light on practices that seek to center oppositional representations of Mexicans. She introduces readers to the world of the tequila industry in the US as it developed over a century. She tracks the marketing of this beverage in both Spanish and English language marketplaces. Juxtaposing perspectives of cultural insiders and outsiders, she demonstrates how very different meanings were attributed to tequila according to nationality and time period. Mexicans marketed tequila as a symbol of national identity, while Anglos framed it as a sign of Mexican deviance. Quite familiar with the negative portrayal by outsiders, Mexicans took control of the image of this product and used it to express ethnic pride and solidarity. 
Holly Straut-Eppsteiner introduces us to a classification of workers we hear very little about, those considered unskilled workers in the $\mathrm{H}-2 \mathrm{~B}$ program for non-agricultural work. This guestworker program allows industries to hire workers from select countries temporarily if they can prove US workers are unavailable. She argues that these workers find themselves in an extremely untenable position. The jaiberas she interviews in the rural Southwest work seasonally and return to Mexico every year. They provide cheap labor for the US seafood industry and have no chance for permanent settlement. Yes, they are providing for their families, often as the sole support, but these women experience long painful separation from their children and partners for extended periods. Straut-Eppsteiner demonstrates how such a system enriches the industry while sustaining precarious conditions for the workers.

In the last article, Noel Zavala offers a timely analysis of sexuality and masculinity in the boxing industry. He seamlessly brings together three related accounts of boxers confronting their queer sexuality: the recent coming out experience of young Puerto Rican boxer Orlando Cruz; the 1962 Benny Paret vs. Emile Griffith bout, which ended disastrously; and the play, Blade to the Heat, which dramatizes the tragic backstory of this fight. Through an insightful analysis of these three narratives, Zavala explores how masculinity is shaped by culture and how gay Latinos are pressured to deny their sexuality or risk being demonized in the hypermasculine world of boxing. The essay highlights the factors that inform Latino masculinity in a space that is especially charged for those of non-normative sexualities.

Each of these articles contributes to our understanding of Latino endeavors in myriad arenas and reminds us of the scope and diversity of those experiences. We follow these articles with two Reflexiones Pedagógicas. Carlos Decena challenges us to consider the development and future of our field given new generations of students and complex transnational movements, while Isabel Martinez advocates for improving the training of Latinas undertaking ethnographic work to ensure their safety and well-being. We round out the issue with a Páginas Recuperadas contribution by Nancy Kang and Silvio Torres-Saillant. They consider historical and current points of connection between Latinos and Asian pan-ethnicities. Their engaging overview interrupts the obsessive focus on black-white racial binaries in accounts of racial formations in the US and illuminates moments of solidarity and discord within Asian-Hispanic interactions. As the US becomes progressively more racially and ethnically diverse, such interethnic connections become increasingly more significant.

Enjoy!

Lourdes Torres

DePaul University, Chicago, IL

E-mail: latstu@depaul.edu 